\title{
THE VALUE OF ANTI-NATAL EXERCISES
}

\author{
By EILEEN E. GUNTER,
}

Diploma of Physical Education, Bergman Osterberg P.T. College, Dartford, Kent, England. Lecturer Sub-Dept. Physiotherapy, Witwatersrand University.

$\mathbf{M}$ ANY varied articles have been written on the controversial subject of exercise for ante-natal patients. The British Journal of Gynaecology and Obstetrics, February, 1956, reproduced statistics drawn up by the Middlesex Hospital, England, of the work done in this field.

In view of the comments made in this article, from which it would appear, ante-natal exercise was of little or no value in relation to length of labour or the incidence of complications of labour, it was decided to carry out an investigation of the patients at The Queen Victoria Hospital who had attended ante-natal classes.

The investigation briefly was based on booked deliveries at the Hospital occurring from $9 / 10 / 54$ to $31 / 7 / 56$. Statistics are produced of 150 patients, all primagravidae, picked at random out of 2,500 patients who have attended antenatal classes at the Johannesburg General Hospital. Comparisons are made with an equivalent number of patients, also primagravidae, whose deliveries occurred during the same period of time, but who did not attend classes.

Ante-Natal Classes.

Patients booked at ante-natal clinic, with the doctors permission, were invited to attend ante-natal classes for exercise, voluntarily, having reached their $20 \mathrm{th}-25$ th week of pregnancy.
The techniques which are taught are based largely on those advocated by the late Mrs. Helen Heardman, special attention being devoted to correct breathing, relaxation and exercise of all muscle groups.

The patients were not segregated into groups according to the stages of pregnancy they had reached, but kept together. New patients at their fourth month of pregnancy did the same exercise as those in their seventh or eighth month, because it was felt that each individual exercised within their own ability.

Six weeks before the patients babies are due, the Mothers attend a separate class for a rehearsal of labour to educate them physically and psychologically for labour. Thus complete confidence in both themselves and those present at their confinements is obtained.

The Staff responsible for these classes were able to attend a number of confinements during the latter part of 1954 and 1955. It was found to be of great assistance to the patients during the first stage of labour. This was discontinued due to numbers of patients and lack of staff.

The number of classes attended by individual patients during their pregnancy is a good deal more than numbers on which previous statistics are based. It is felt that this has an important bearing on the results achieved.

CLASSIFICATION OF PRIMAGRAVIDAE. AGE. TYPE OF DELIVERY.

\begin{tabular}{|c|c|c|c|c|c|c|c|c|c|c|}
\hline & Age & & $\begin{array}{l}\text { Normal } \\
\text { Vertex } \\
\text { Delivery }\end{array}$ & $\%$ & $\begin{array}{l}\text { Spontaneous } \\
\text { Face to } \\
\text { Putes }\end{array}$ & $\begin{array}{c}\text { Forceps } \\
\text { Extraction }\end{array}$ & Breech & $\begin{array}{l}\text { Caesarean } \\
\text { Resection }\end{array}$ & $\%$ & Total \\
\hline \multirow{2}{*}{ 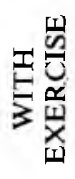 } & $\begin{array}{l}\text { Under } 20 \\
20-29 \\
30-39 \\
\text { Over } 40\end{array}$ & $\begin{array}{c}\ldots \ldots . \\
\cdots \cdots . . \\
\cdots \cdots . . \\
\cdots \cdots . .\end{array}$ & $\begin{array}{r}5 \\
105 \\
16 \\
1\end{array}$ & & $\overline{1}$ & $\begin{array}{l}2 \\
8 \\
2\end{array}$ & $\begin{array}{l}1 \\
2 \\
1\end{array}$ & $\begin{array}{l}1 \\
3 \\
1 \\
1\end{array}$ & & $\begin{array}{r}9 \\
119 \\
20 \\
2\end{array}$ \\
\hline & TOTAL & $\ldots . .$. & 127 & $84 \cdot 7$ & 1 & 12 & 4 & 6 & $15 \cdot 3$ & 150 \\
\hline \multirow{2}{*}{ 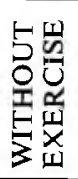 } & $\begin{array}{l}\text { Under } 20 \\
20-29 \\
30-39 \\
\text { Over } 40\end{array}$ & $\begin{array}{c}\ldots \ldots . . \\
\cdots \cdots . . \\
\ldots \ldots . . \\
\cdots \cdots . .\end{array}$ & $\begin{array}{r}37 \\
78 \\
5 \\
-\end{array}$ & & : & $\begin{array}{l}4 \\
5 \\
5\end{array}$ & $\begin{array}{l}1 \\
5 \\
1\end{array}$ & $\begin{array}{l}1 \\
2 \\
4 \\
2\end{array}$ & & $\begin{array}{r}43 \\
90 \\
15 \\
2\end{array}$ \\
\hline & TOTAL & 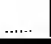 & 120 & $80 \cdot 0$ & & 14 & 7 & 9 & $20 \cdot 0$ & 150 \\
\hline
\end{tabular}

Average Length of Labour. Normal Deliveries.

Exercised Group:

1st Stage Labour -8 hrs. 21 mins. 2nd Stage Labour 32 mins.

3rd Stage Labour 10 mins.
Without Exercise Group:

14 hrs. 19 mins.

30 mins.

$13 \cdot 5$ mins.

TOTAL DIFFERENCE: 1 st Stage Labour: $5 \mathrm{hrs}$. 58 mins. less labour for the exercised group.

FREQUENCY OF ATTENDANCE AT CLASS EXERCISE IN RELATION TO AVERAGE LENGTH OF LABOUR.

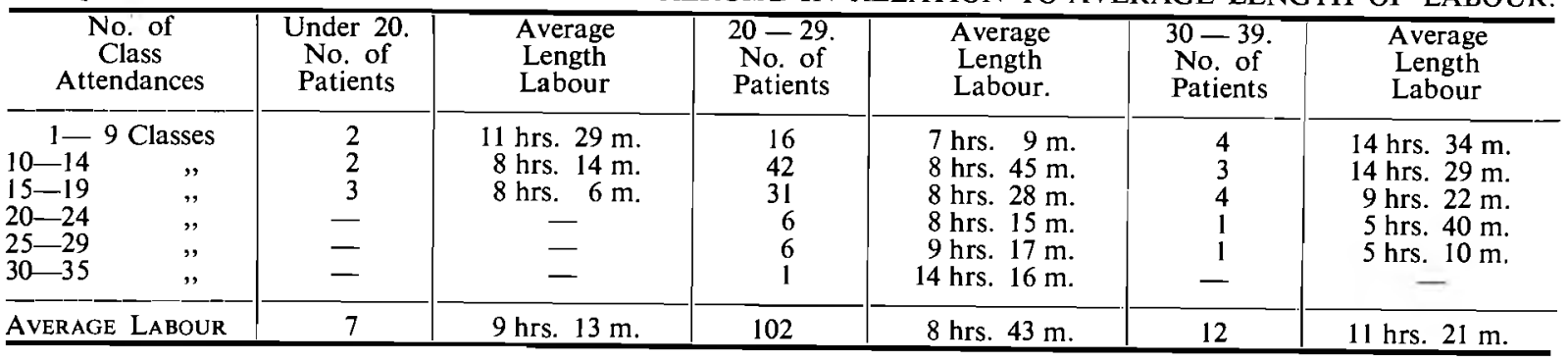


DETAILED TABLE AVERAGE LENGTH OF LABOUR. Normal Deliveries.

WITH EXERCISE

\begin{tabular}{|c|c|c|c|c|}
\hline $\begin{array}{l}\text { Average Lengith } \\
\text { of Labour. }\end{array}$ & $\begin{array}{c}\text { Age } \\
\text { Under 20 }\end{array}$ & $\begin{array}{c}\text { Age } \\
20-29\end{array}$ & $\begin{array}{c}\text { Age } \\
30-39\end{array}$ & $\begin{array}{c}\text { Age } \\
\text { Over } 40\end{array}$ \\
\hline $\begin{array}{l}\text { First Stage } \\
\text { Second Stage } \\
\text { Third Stage }\end{array}$ & $\begin{array}{cc}\text { hrs. } & \text { m. } \\
8 & 42 \\
0 & 24 \\
0 & 7\end{array}$ & $\begin{array}{cc}\text { hrs. } & \text { m. } \\
8 & 0 \\
0 & 33 \\
0 & 10\end{array}$ & $\begin{array}{cc}\text { hrs. } & \mathrm{m} . \\
10 & 34 \\
0 & 35 \\
0 & 12\end{array}$ & $\begin{array}{cc}\text { hrs. } & \text { m. } \\
3 & 30 \\
0 & 46 \\
0 & 11\end{array}$ \\
\hline$T$ & $\begin{array}{l}9 \\
9\end{array}$ & $\begin{array}{l}8 \quad 43 \\
\end{array}$ & $\begin{array}{ll}11 \quad 21 \\
1\end{array}$ & $\begin{array}{ll}4 & 27 \\
\end{array}$ \\
\hline
\end{tabular}

WITHOUT EXERCISE:

\begin{tabular}{l|rr|rr|rr|c}
\hline First Stage & hrs..... & 12 & 30 & hrs. & m. & hrs. $\mathrm{m}$. & hrs. m. \\
Second Stage & 0 & 26 & 0 & 31 & 9 & 0 & - \\
Third Stage ...... & 0 & 15 & 0 & 13 & 0 & 46 & - \\
\hline TOTAL LABOUR & 13 & 11 & 14 & 21 & 9 & 58 & - \\
\hline
\end{tabular}

\section{FREQUENCY OF ATTENDANCE AT CLASS EXERCISE.}

Normal Deliveries.

\begin{tabular}{l|c|c|c|c|c|c}
\hline $\begin{array}{l}\text { Possible } \\
\text { Attendances ...... }\end{array}$ & $1-9$ & $10-14$ & $15-19$ & $20-24$ & $25-29$ & $\begin{array}{c}\text { Over } \\
30\end{array}$ \\
\hline $\begin{array}{l}\text { No. Classes } \\
\text { P a t i e n t s } \\
\text { Attended .... }\end{array}$ & 23 & 46 & 38 & 7 & 7 & 1 \\
\hline
\end{tabular}

\section{COMPLICATIONS OF PREGNANCY AND} INCIDENCE OF TOXAEMIA.

\begin{tabular}{c|c|c|c|c|c}
\hline & $\begin{array}{c}\text { Under } \\
20\end{array}$ & $20-29$ & $30-39$ & $\begin{array}{c}\text { Over } \\
40\end{array}$ & Total \\
\hline \begin{tabular}{c} 
With Exercise \\
\hline $\begin{array}{c}\text { Without Exer- } \\
\text { cise …...... }\end{array}$
\end{tabular} & 6 & 10 & 2 & - & 20 \\
\hline
\end{tabular}

COMPLICATIONS OF LABOUR.

Lacerations and Episiotomies:

\begin{tabular}{l|c|c|c|c|c}
\hline With Exercise & 4 & 53 & 8 & - & 65 \\
\hline $\begin{array}{c}\text { Without Exer- } \\
\text { cise .......... }\end{array}$ & 16 & 53 & 6 & - & 75 \\
\hline
\end{tabular}

Incidence of Prolonged Labour :

\begin{tabular}{l|c|c|c|c|c}
\hline With Exercise & 1 & 9 & 1 & - & 11 \\
\hline $\begin{array}{l}\text { Without Exer- } \\
\text { cise }\end{array}$ & 3 & 7 & 2 & - & 12 \\
\hline
\end{tabular}

Post-partum Haemorrhage. Over 10-ozs.:

\begin{tabular}{c|c|c|c|c|c}
\hline & $\begin{array}{c}\text { Under } \\
20\end{array}$ & $20-29$ & $30-39$ & $\begin{array}{c}\text { Over } \\
40\end{array}$ & Total \\
\hline $\begin{array}{c}\text { With Exercise } \\
\begin{array}{c}\text { Without Exer- } \\
\text { cise ........... }\end{array}\end{array}$ & 10 & 17 & 3 & & 30 \\
\hline
\end{tabular}

Posterior Presentations:

\begin{tabular}{|c|c|c|c|c|c|}
\hline & $\begin{array}{c}\text { Under } \\
20\end{array}$ & $20-29$ & $30-39$ & $\begin{array}{c}\text { Over } \\
40\end{array}$ & Total \\
\hline With Exercise & 1 & 2 & - & - & 3 \\
\hline $\begin{array}{l}\text { Without Exer- } \\
\text { cise }\end{array}$ & 2 & 3 & 1 & - & 6 \\
\hline
\end{tabular}

Caesarean Resections:

\begin{tabular}{c|c|c|c|c|c}
\hline & $\begin{array}{c}\text { Under } \\
20\end{array}$ & $20-29$ & $30-39$ & $\begin{array}{c}\text { Over } \\
40\end{array}$ & Total \\
\hline $\begin{array}{c}\text { With Exercise } \\
\begin{array}{c}\text { Without Exer- } \\
\text { cise .......... }\end{array}\end{array}$ & 1 & 3 & 1 & 1 & 6 \\
\hline
\end{tabular}

Discussion:

Ante-natal exercise is proved of extreme value in relation to the average length of labour by the fact that the exercised group of patients had six hours less labour than the non-exercised group in first stage labour. It is of great interest that the older patients with the greater amount of exercise had very much shorter labour. It would therefore seem apparent that the older the patient the greater the the need for exercise.

Exercise also would appear to have an effect on both the complications of pregnancy and labour. In all cases the exercised group have benefited. Half the number of patients had complications of pregnancy, and the same figure of post-partum haemorrhage.

The proportionate figures in both exercised and nonexercised patients who had tears and episiotomies is at an extremely high level and therefore' requires further extensive investigation. Bearing in mind that a fáir percentage are due to foetal distress, prolonged labour or uterine inertia, a large proportion of exercised patients require episiotomies due to tight peroneums.

Previous statistics, in particular those drawn up by the Middlesex Hospital have been based on figure where the average amount of exercise given (average attendance during pregnancy-five classes) is very much less than the attendances of the patients upon which these figures are based, (average attendance during pregnancy-fifteen classes). It is felt that this has a most important bearing on the results achieved.

\section{SUMMARY.}

Exercise is of value to ante-natal patients demonstrated in the Table of Average Length of Labour. $6 \%$ of the patients in the exercised group experienced complications of pregnancy as against $12 \%$ in the non-exercised group.

The outstanding figures for the complications of labour are firstly, that $7 \%$ less patients in the exercised group had lacerations and episiotomies and $10 \%$ less of the same group with large post-partum haemorrhages.

It is not possible at this juncture to produce figures showing the effects of exercise on the mother post-natally. Broadly however, the tone of the abdominal muscles in particular, are generally good and the posture naturally good, too.

Physical and psychological education are therefore considered to be of great importance and an integral part of the work by the physiotherapist for the expectant mother.

I would like to express my deep appreciation to Dr. J. H. GEAR for his invaluable help, also to the staff of the Queen Victoria Hospital. 